\title{
Facultative-anaerobic microbial digestion of coal preparation waste and use of effluent solids to enhance plant growth in a sandy soil
}

\author{
Paul H. Fallgren ${ }^{1,2} \cdot$ Liang Chen ${ }^{2,3} \cdot$ Min Peng $^{2} \cdot$ Michael A. Urynowicz ${ }^{4}$. \\ Song Jin ${ }^{1,4}$
}

Received: 28 March 2020/Revised: 26 August 2020/Accepted: 15 October 2020/Published online: 22 November 2020

(C) The Author(s) 2020

\begin{abstract}
Coal preparation solid waste, which is a major environmental issue for coal-producing areas in China, may be microbiologically digested and transformed into a product suitable as a soil amendment to increase soil organic matter content and prevent and enhance plant/crop growth. Coal preparation waste collected from a coal sorting plant in Inner Mongolia, China was digested in bioreactors inoculated with microbial enrichments prepared from activated sludge and cow manure. The effluent solids from the coal preparation waste bioreactors were analyzed for their suitability as organic soil amendments, which complied with China standards. Plant growth tests were conducted in sandy soil from a semi-arid region in Colorado, which was amended with the effluent solids. Kentucky bluegrass (Poa pratensis L.) and chives (Allium schoenoprasum) were used as the representative plants for the growth tests, where results indicated substantially higher yields of Kentucky bluegrass and chives for the sandy soils amended with the effluent solids when compared to a commercial organic fertilizer. The number and average length of Kentucky bluegrass shoots were 10 and 5.1 times higher, respectively, in soils amended with the effluent solids. Similarly, the number and average length of chives shoots were 10 and 1.7 times higher, respectively, in soils amended with the effluent solids. Overall, the microbial digestion of coal preparation waste for application as an organic soil amendment is a viable alternative and beneficial use of coal preparation solid waste.
\end{abstract}

Keywords Coal processing waste $\cdot$ Coal washing slime $\cdot$ Soil amendment $\cdot$ Soil restoration $\cdot$ Waste beneficiation . Anaerobic digestion

Song Jin

sjin@uwyo.edu

1 Advanced Environmental Technologies, LLC, Fort Collins, Colorado 80525, USA

2 Apaxfon Biosciences Technologies Co., Ltd, Baotou 014100, Inner Mongolia, China

3 School of Civil Engineering, Tianjin University, Tianjin 300072, China

4 Department of Civil and Architectural Engineering, University of Wyoming, Laramie, Wyoming 82071, USA

\section{Introduction}

Coal industry waste, particularly wastes from coal preparation (washing), is a continuing environmental issue for coal producing areas in China. Coal preparation solid wastes are currently one of the largest industrial hazards in China in terms of land area and accumulation, which amplifies the environmental hazards associated with the wastes (Fu et al. 2012; Zhou et al. 2014; Li et al. 2015; Liang et al. 2016; Zhao and Luo 2017). To mitigate the accumulation of coal preparation waste, remedies development has primarily focused on beneficial reuse of the material, which includes uses in construction materials, zeolites, activated carbons, and a variety of sorbents ( $\mathrm{Li}$ et al. 2006; Yan et al. 2010; Zhou et al. 2014; Gao et al. 2015); however, these uses have not been developed to a 
level where the demand utilizes any significant quantities of coal preparation waste. Alternative uses that have the potential to require substantial quantities of coal preparation waste may be for the agricultural and land management/restoration industries.

Soil degradation and alkalinization are major agricultural and environmental issues, especially in areas such as the Inner Mongolia Autonomous Region in China (Akiyama and Kawamura 2007). Major crop production is hindered by the prevalence of alkali soil in arid and semiarid regions such as Inner Mongolia. A major characteristic of these soils is the lack of organic matter. Organic matter is important for soil health, where it enhances soil structure and aggregation, improves water holding capacity, and supports microbial activity that are important to nutrient cycling. Low-rank coals (e.g., lignite) have been used as raw materials for soil amendments to improve soil organic matter content, primarily from the humic material that exists in low-rank coals (Kwiatkowska et al. 2008; Giannouli et al. 2009; Kirn et al. 2010; Cubillos-Hinojosa et al. 2015), where commercial potential of using low-rank coals for soil amendments has been explored (Fiscor 2016); however, coal compounds are typically not immediately available and readily degradable for soil microorganisms, which increases the time for realizing the benefits of lowrank coals as soil amendments. One solution is the microbial digestion of low-rank coals prior to their use as soil amendments.

It has long been known that microorganisms can digest coal compounds and this capability has been exploited and enhanced for processes such as biogasification (bioenergy), biodesulfurization, and production of other potentially beneficial substances (Stoner et al. 1990; Faison 1991; Isbister and Barik 1993; Gupta and Birendra 2000; Gokcay et al. 2001; Jin 2007; Fallgren et al. 2013a, b; Gupta and Gupta 2014; Sudheer et al. 2016; David et al. 2017). Microbial coal digestion is conducted by a consortium of facultative and anaerobic microorganisms, where Fig. 1 shows a simplified process for microbial coal digestion typically found in enhanced systems (i.e., bioreactors or in situ coalbed treatments) and is based on the mechanisms presented by Strapoc et al. $(2008,2011)$. The first step of microbial coal digestion is coal fragmentation and depolymerization into smaller coal components. This step is primarily conducted by aerobic and facultative microorganisms due to their abundance and production enzymes capable of oxidizing and hydrolyzing complex compounds under conditions favorable to aerobic/facultative pathways. Further depolymerization and activation of coal components are conducted by both facultative and anaerobic microorganisms, producing both insoluble and soluble intermediates. Fermentation of the intermediates by anaerobic microorganisms results in compounds that are utilized by methanogenic microorganisms to produce methane. Typically, most coal components are very recalcitrant toward microbial depolymerization; therefore, only a small fraction of the coal is transformed into gas, while the remaining coal components are insoluble fragmented and activated solids. Chemical pretreatments to increase coal depolymerization has been explored for increasing methane production for energy recovery (Huang et al. 2013; Liu et al. 2019, Wang et al. 2019); however, for the purpose of transforming low-rank coal to more bioavailable form for soil amendments, the loss of important coal components as methane is greater with these chemical pretreatments. Without any chemical pretreatment, the microbial digestion of low-rank coal is expected to produce solids consisting of fragmented and activated coal components, while producing biogas (methane and carbon dioxide) that indicate the level of digestion.

A substantial portion of coal preparation waste contains the organic fractions from coal, the use of coal preparation waste as a soil amendment has been previously explored (Wang et al. 2009); however, the same limitations are present as with the original coal parent material. Since coal preparation waste currently produced in China are composed of high fractions of organic carbon (the parent coal itself), the coal preparation waste may be microbiologically digested and transformed into a product suitable as a soil amendment to increase soil organic matter content and prevent or reverse soil degradation and enhance plant/crop growth. The objective of the following research was to demonstrate the microbial digestion of coal preparation waste and the suitability of the resulting effluent solids on enhancing plant growth.

\section{Methods and materials}

\subsection{Coal processing waste}

The coal processing (washing) waste solids used for the experiments were acquired from a coal preparation plant located near Baotou (Inner Mongolia, China). This coal preparation plant processes low-rank coals from several mines in Inner Mongolia, and it uses froth flotation as its processing (washing) method. The slime from the coal processing was dewatered and air-dried prior to collection. The parent material of the coal processing waste solids is lignite from a mine in the Ordos Basin (Inner Mongolia, China), where samples of lignite from this mine were also acquired for the experiments. 


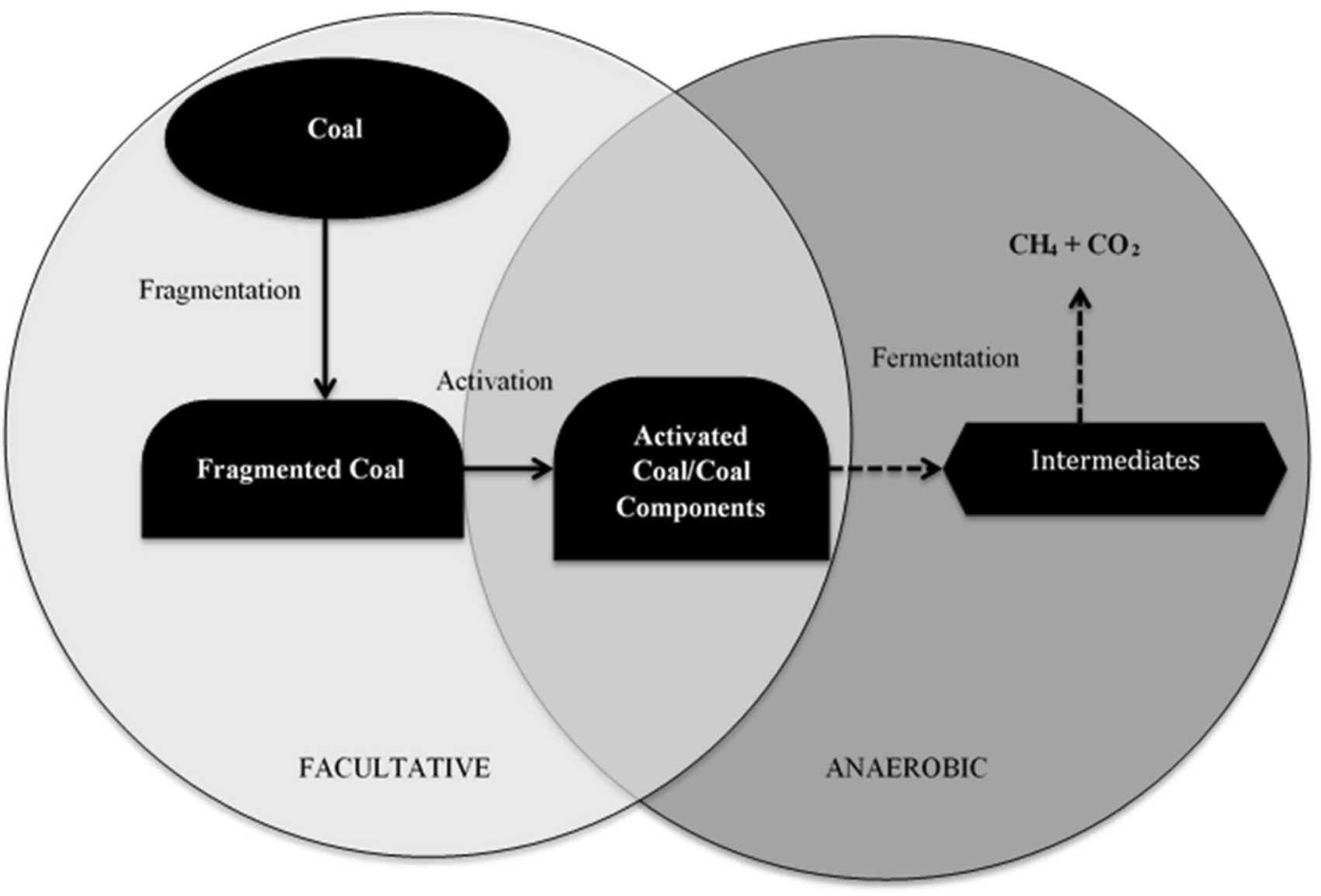

Fig. 1 Microbial digestion of coal process

\subsection{Bioreactors setup and operation}

\subsubsection{Microbial enrichment (Inner Mongolia)}

The Inner Mongolia microbial enrichment was prepared by using materials sourced in the Baotou, Inner Mongolia area. For the microbial digestion of coal processing waste solids, sources for both facultative and anaerobic microorganisms were sourced from activated sludge and cow manure. Dewatered activated sludge was collected from a municipal wastewater treatment plant in a rural area near Baotou. The cow manure was collected from a dairy farm near Baotou. Groundwater was used as the liquid medium and was collected from a well in Baotou. The groundwater was autoclaved for $1 \mathrm{~h}$ prior to use.

The microbial enrichment was prepared under nitrogen $\left(\mathrm{N}_{2}\right)$ purging, where a proprietary nutrient mixture was added to the groundwater, which was based on growth media described in Fallgren et al. (2013a, b) and Jin (2007). Under continuous stirring and $\mathrm{N}_{2}$ purging, the activated sludge was added to a concentration of $1 \mathrm{~g} / \mathrm{L}$. Similarly, the cow manure was added to the enrichment medium to concentration of $1 \mathrm{~g} / \mathrm{L}$. The $\mathrm{pH}$ of the enrichment mixture was adjusted to 6.8 , and then the mixture was incubated in a sealed reactor at $35{ }^{\circ} \mathrm{C}$ for $7 \mathrm{~d}$ prior to use. The gas produced from the enrichment medium was released and collected in gas bags.

\subsubsection{Bioreactor startup, operation, and monitoring}

Glass batch bioreactors with $5 \mathrm{~L}$ capacities were constructed to be sealable and gas-tight. Each reactor was constructed with one liquid sampling port and valve, and one gas outlet with a sampling port. The gas was collected in a separate vessel, which displaced water. The gas production volume was determined from the volume of the displaced water from the gas collection vessel. The batch bioreactor temperatures were controlled using heated water baths.

The experimental batch bioreactor runs were conducted with three different feed mixtures: (1) Inner Mongolia microbial enrichment (5 L liquid); (2) coal processing waste solids $(500 \mathrm{~g})$ and Inner Mongolia microbial enrichment (4.5 L liquid); and (3) lignite (500 g) and Inner Mongolia microbial enrichment (4.5 L liquid). All bioreactors were loaded and sealed while being purged with $\mathrm{N}_{2}$. 
The bioreactors were heated in water baths with reactor temperatures being maintained at $35{ }^{\circ} \mathrm{C}$. Gas production was monitored daily by measuring the volume of displaced water from the gas collection vessel. The batch bioreactor runs were stopped after 120 days.

The slurries in the bioreactors with solid/liquid mixtures were discharged, dewatered, and dried, where the solid products were collected and characterized. Characterization parameters were based on the China standard for organic soil amendments. These parameters included: moisture, organic matter, $\mathrm{pH}$, nitrogen $(\mathrm{N})$, phosphorus (as $\mathrm{P}_{2} \mathrm{O}_{5}$ ), potassium (as $\mathrm{K}_{2} \mathrm{O}$ ), arsenic, mercury, lead, cadmium, chromium, locust/ascaris eggs mortality, and total coliforms. The raw coal-processing waste solids were also characterized for comparison.

\subsection{Plant growth tests}

\subsubsection{Bioreactor for effluent solids production}

Glass batch bioreactors similar to the bioreactors constructed as described in Sect. 2.2.2 were used for producing the effluent solids required for the plant growth tests. These bioreactors used a Colorado microbial enrichment that was prepared by using materials sourced in the Northern Colorado (USA) area. The microbial enrichment was prepared the same way as that described in Sect. 2.2.1, except for the following: (1) the activated sludge was collected from the Drake Water Reclamation Facility (Fort Collins, Colorado, USA); (2) the cow manure was collected from a dairy farm near Fort Collins, Colorado; and (3) the groundwater was collected from a well near Fort Collins, Colorado.

The batch reactor runs for producing effluent solids for the plant growth tests were conducted with two different feed mixtures: (1) Colorado microbial enrichment $(5 \mathrm{~L}$ liquid); and (2) coal processing waste solids from Inner Mongolia (500 g) and Colorado microbial enrichment (5 L liquid). All bioreactors were loaded and sealed while being purged with $\mathrm{N}_{2}$. The bioreactors were heated in water baths with reactor temperatures being maintained at $35^{\circ} \mathrm{C}$. Gas production was monitored daily by measuring the volume of displaced water from the gas collection vessel. Bioreactor headspace gas samples were also collected and analyzed for methane and carbon dioxide composition. The batch bioreactor runs were stopped after 120 days, where the bioreactor contents (slurry) were discharged, dewatered, and dried prior to use for the plant growth tests.

\subsubsection{Plant growth tests setup and monitoring}

The sandy soil used for the growth tests was collected from a sand pile at a landscaping material supplier in Loveland, Colorado. The sandy soil was added to pots divided into three sets: (1) sandy soil only; (2) commercial organic fertilizer-amended sandy soil; and (3) microbial digestion effluent solids-amended sandy soil. The commercial organic fertilizer (Nature's Care Organic \& Natural Plant Food, Ohio, USA) was added to the sandy soil at a rate equivalent to $1.5 \mathrm{~kg} / \mathrm{m}^{2}$. Similarly, the effluent solids were added to the sandy soil at a rate equivalent to $1.5 \mathrm{~kg} / \mathrm{m}^{2}$. The soil amendments were mixed in with the soil in the pots prior to use.

The plant growth experiments were conducted for two different plants: Kentucky bluegrass (Poa pratensis L.) and chives (Allium schoenoprasum). Each plant growth experiment included the three soil conditions described above. The Kentucky bluegrass growth tests were conducted by planting 120 seeds in each pot for each soil condition. The pots were watered daily and incubated at approximately 20-23 ${ }^{\circ} \mathrm{C}$ under a growth lamp set for $12 \mathrm{~h} /$ day. The Kentucky bluegrass growth tests run was stopped after 42 days. The chives growth tests were conducted by planting 30 seeds in each pot for each soil condition. These pots were also watered daily and incubated at approximately $20-23{ }^{\circ} \mathrm{C}$ under a growth lamp set for $12 \mathrm{~h} /$ day. The chives growth tests stopped running after 25 days. During the growth test period, the number of grass or chives stalks and mean plant heights were monitored. After the stop of the growth tests, the grass or chives were harvested where the mean total plant lengths, mean root lengths, mean number of root branches, and total biomasses were determined.

\subsection{Analytical}

Bioreactor headspace gas samples were analyzed for methane and carbon dioxide compositions, which were measured by a gas chromatograph (Shimadzu 8A, Japan) equipped with a thermal conductivity detector and a Carboxen 1000 packed column $(4.6 \mathrm{~m} \times 1 / 8$ in $\times 2.1 \mathrm{~mm})$. Solids moisture was determined by the drying-weighing method (Chinese standard method GB/T8576-2010). Solids organic matter was determined by the potassium dichromate volumetric method (Chinese standard method NY525-2012). Solids slurry $\mathrm{pH}$ was determined by using a FE28 pH meter (Mettler Toledo Instruments Shanghai Co., Ltd., Shanghai, China). Solids nitrogen (as N) content was determined by digesting samples with an aluminum film block digester then quantified by a K1305B Kjeldahl unit (Shanghai Shengsheng Automatic Analysis Instrument Co., Ltd., Shanghai, China) by following Chinese standard method NY525-2012. Solids phosphorus (as $\mathrm{P}_{2} \mathrm{O}_{5}$ ), potassium (as $\left.\mathrm{K}_{2} \mathrm{O}\right)$, lead $(\mathrm{Pb})$, cadmium $(\mathrm{Cd})$, and total chromium $(\mathrm{Cr})$ were measured by the ICP-Mass (Thermo Fisher, Maryland, USA). Arsenic (As) and mercury (Hg) were determined by an atomic fluorescence 

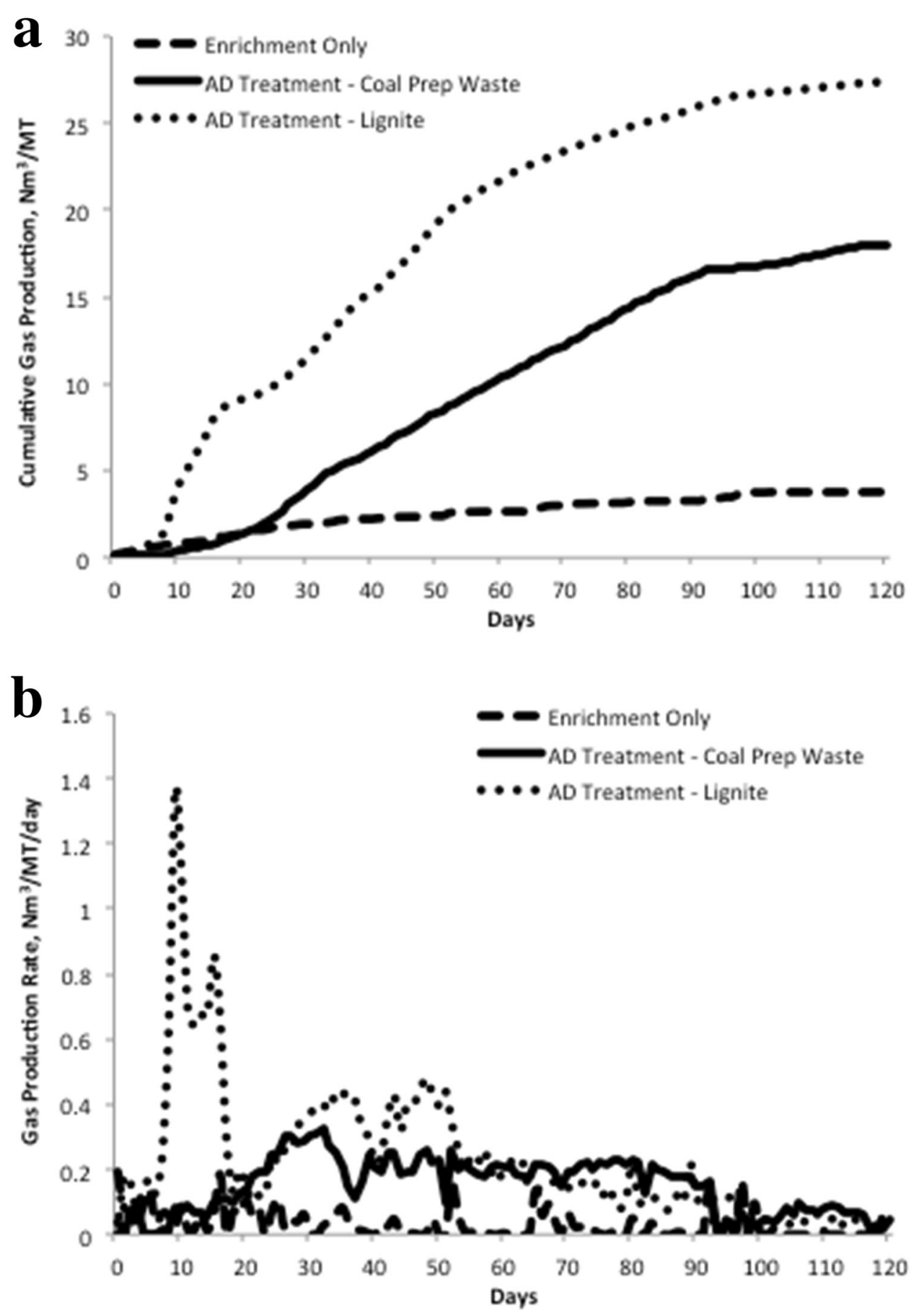

Fig. 2 a Cumulative total gas production from the microbial digestion bioreactors amended with the Inner Mongolia microbial enrichment. (Note: $\mathrm{Nm}^{3}=$ normal cubic meters; MT = metric ton) $\mathbf{b}$ Total gas production rates from the microbial digestion bioreactors amended with the Inner Mongolia microbial enrichment

spectrophotometer (Beijing Haiguang Instrument Co., Ltd., Beijing, China). The locust/ascaris eggs mortality in the solids was determined by the biomicroscopy method (Chinese standard method (GB/T19524.2-2004)). The total coliforms in the solids were determined by Gram staining.

\section{Results and discussion}

\subsection{Microbial digestion of coal processing waste}

Microbial digestion, such as anaerobic digestion (AD), has long been used to convert wastes (food and agriculture 
Table 1 Material analysis results for raw coal preparation (washing) waste and the microbial digestion effluent solids. The characterization parameters are based on the China standard requirements for organic soil amendments

\begin{tabular}{|c|c|c|c|}
\hline Parameter & $\begin{array}{l}\text { Raw coal } \\
\text { preparation } \\
\text { (washing) } \\
\text { waste }\end{array}$ & $\begin{array}{l}\text { Microbial } \\
\text { digestion } \\
\text { effluent } \\
\text { solids (dried) }\end{array}$ & $\begin{array}{l}\text { Organic soil } \\
\text { amendment } \\
\text { standard } \\
\text { (China) }\end{array}$ \\
\hline Moisture (\%) & 31 & 23 & $\leq 30$ \\
\hline $\begin{array}{l}\text { Organic Matter (mg/ } \\
\text { kg) }\end{array}$ & 149 & 97 & $\geq 45$ \\
\hline $\mathrm{pH}$ & 7.4 & 7.2 & $5.5-8.5$ \\
\hline Nitrogen $(\mathrm{N})(\%)$ & 0.7 & 0.5 & - \\
\hline $\begin{array}{l}\text { Phosphorus } \\
\qquad\left(\mathrm{P}_{2} \mathrm{O}_{5}\right)(\%)\end{array}$ & 1.0 & 1.0 & - \\
\hline Potassium $\left(\mathrm{K}_{2} \mathrm{O}\right)(\%)$ & 0.1 & 0.6 & - \\
\hline $\mathrm{N}+\mathrm{P}_{2} \mathrm{O}_{5}+\mathrm{K}_{2} \mathrm{O}(\%)$ & 1.8 & 2.1 & $\geq \begin{array}{l}\geq .0 \text { (for } \\
\text { fertilizer) }\end{array}$ \\
\hline Arsenic (As) (mg/kg) & 0.8 & 2 & $\leq 15$ \\
\hline Mercury $(\mathrm{Hg})(\mathrm{mg} / \mathrm{kg})$ & $<0.1$ & $<0.1$ & $\leq 2$ \\
\hline Lead $(\mathrm{Pb})(\mathrm{mg} / \mathrm{kg})$ & 3 & 10 & $\leq 50$ \\
\hline $\begin{array}{l}\text { Cadmium (Cd) (mg/ } \\
\text { kg) }\end{array}$ & 0.4 & 0.6 & $\leq 3$ \\
\hline $\begin{array}{l}\text { Chromium }(\mathrm{Cr})(\mathrm{mg} / \\
\mathrm{kg})\end{array}$ & 6 & 14 & $\leq 150$ \\
\hline $\begin{array}{l}\text { Locust/ascaris eggs } \\
\text { mortality }(\%)\end{array}$ & 100 & 100 & $\geq 95$ \\
\hline Total coliforms (cfu/g) & 43 & $<3$ & $\leq 100$ \\
\hline
\end{tabular}

wastes, sewage sludge, livestock wastes) and energy crops into primarily two useful by-products: biogas and fertilizer/soil amendments (Nkoa 2014). Typically, the readily biodegradable fraction of these feedstocks are converted to biogas, leaving behind a stabilized organic matrix (composed of more recalcitrant compounds) that has agronomic value; therefore, the level of biogas production is an indicator of the level of solids degradation and transformation. However, unlike the wastes and energy crops, coal requires fragmentation, depolymerization, and activation. In this case, the biogas production level is an indicator of the level of activation of coal compounds.

The biogas production was monitored in $\mathrm{AD}$ reactors containing coal preparation waste and the parent coal material (i.e., lignite). Biogas production was analyzed in terms of normal cubic meters $\left(\mathrm{Nm}^{3}\right)$ gas production per metric ton (MT) of total reactor contents (i.e., solid-liquid slurry or water with the microbial enrichment) in the reactors. From the total produced gas accumulation (Fig. 2a), AD reactors containing lignite and coal preparation waste produced significantly more gas (27.3 and $8.84 \mathrm{Nm}^{3} / \mathrm{MT}$ from reactors with lignite and coal preparation waste, respectively) than the reactor containing only
Fig. 3 a Cumulative total gas production from the microbial digestion bioreactors amended with the Colorado microbial enrichment. "Enrichment Only" bioreactors contained no coal preparation waste solids. "AD Treatment" bioreactors contained both the microbial enrichment and the coal preparation waste solids. b Methane composition of the gas produced from the microbial digestion bioreactors amended with the Colorado microbial enrichment. "Enrichment Only" bioreactors contained no coal preparation waste solids. "AD Treatment" bioreactors contained both the microbial enrichment and the coal preparation waste solids. $\mathbf{c}$ Carbon dioxide composition of the gas produced from the microbial digestion bioreactors amended with the Colorado microbial enrichment. "Enrichment Only" bioreactors contained no coal preparation waste solids. "AD Treatment" bioreactors contained both the microbial enrichment and the coal preparation waste solids

the microbial enrichment $\left(3.76 \mathrm{Nm}^{3} / \mathrm{MT}\right)$. This indicates that microbial digestion of the lignite and coal preparation wastes were occurring in the reactors, where higher amounts of organic compounds from lignite were available for gas production by the microorganisms than were present from the coal preparation waste (mean difference in gas production through 120 days was determined be $8.84 \mathrm{Nm}^{3} / \mathrm{MT}$ ). Daily gas production rate monitoring indicated that the majority of the gas produced from lignite was produced between 8 and 19 days after reactor startups (Fig. 2b), where rates of $0.64-1.36 \mathrm{Nm}^{3} / \mathrm{MT}$ per day were observed (approximately $72 \%-266 \%$ higher than observed from coal preparation waste). This indicates the presence of relatively smaller and more bioavailable compounds in the lignite parent material. Huang et al. (2018) observed that a small fraction of smaller lees complex coal compounds from low rank coal are readily dissolved in water, which may be more quickly converted to gas early in a reactor run. Fallgren et al. (2013a) observed that trapped volatile organic compounds in coal may significantly contribute to microbial gas production after microbial coal fragmentation and depolymerization. After 19 days, the gas production rate from lignite decreased and stabilized to similar levels as the gas production rates from AD reactors containing coal preparation waste (mean gas production rate of $0.149 \mathrm{Nm}^{3} /$ MT per day).

Coal preparation waste is composed of the parent lignite material; however, the majority of more volatile organic compounds and other smaller less complex compounds have been removed during the coal preparation (washing) process. Therefore, coal preparation waste the gas produced is primarily from the products of the fermentation of compounds activated after depolymerization. Similar to $\mathrm{AD}$ of other materials, the biogas production rate decreases with less readily bioavailable and soluble compounds. This decrease in gas production rate is an indicator the microbial digestion level of the solids, and their readiness for use as soil amendments. Gas production from the coal preparation 

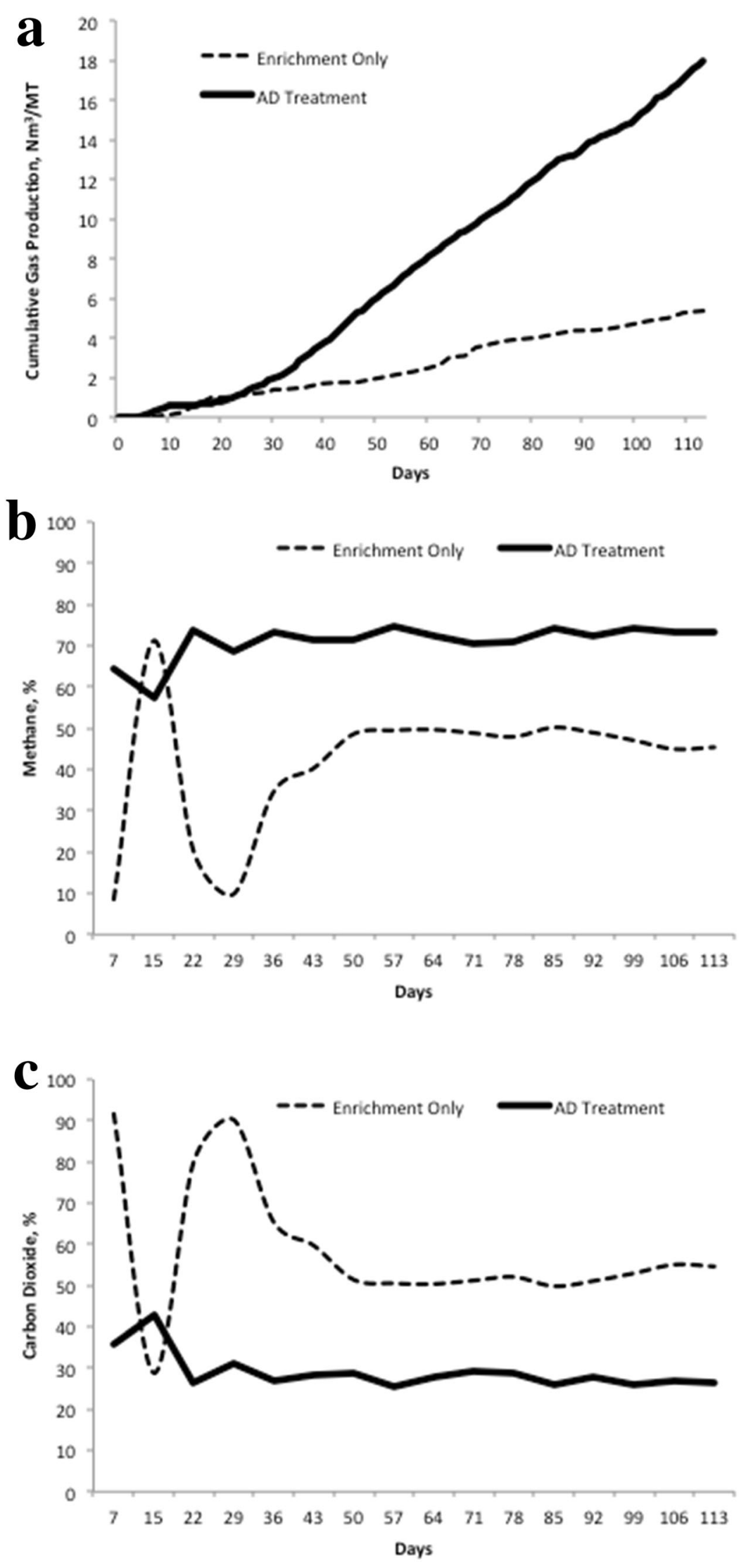

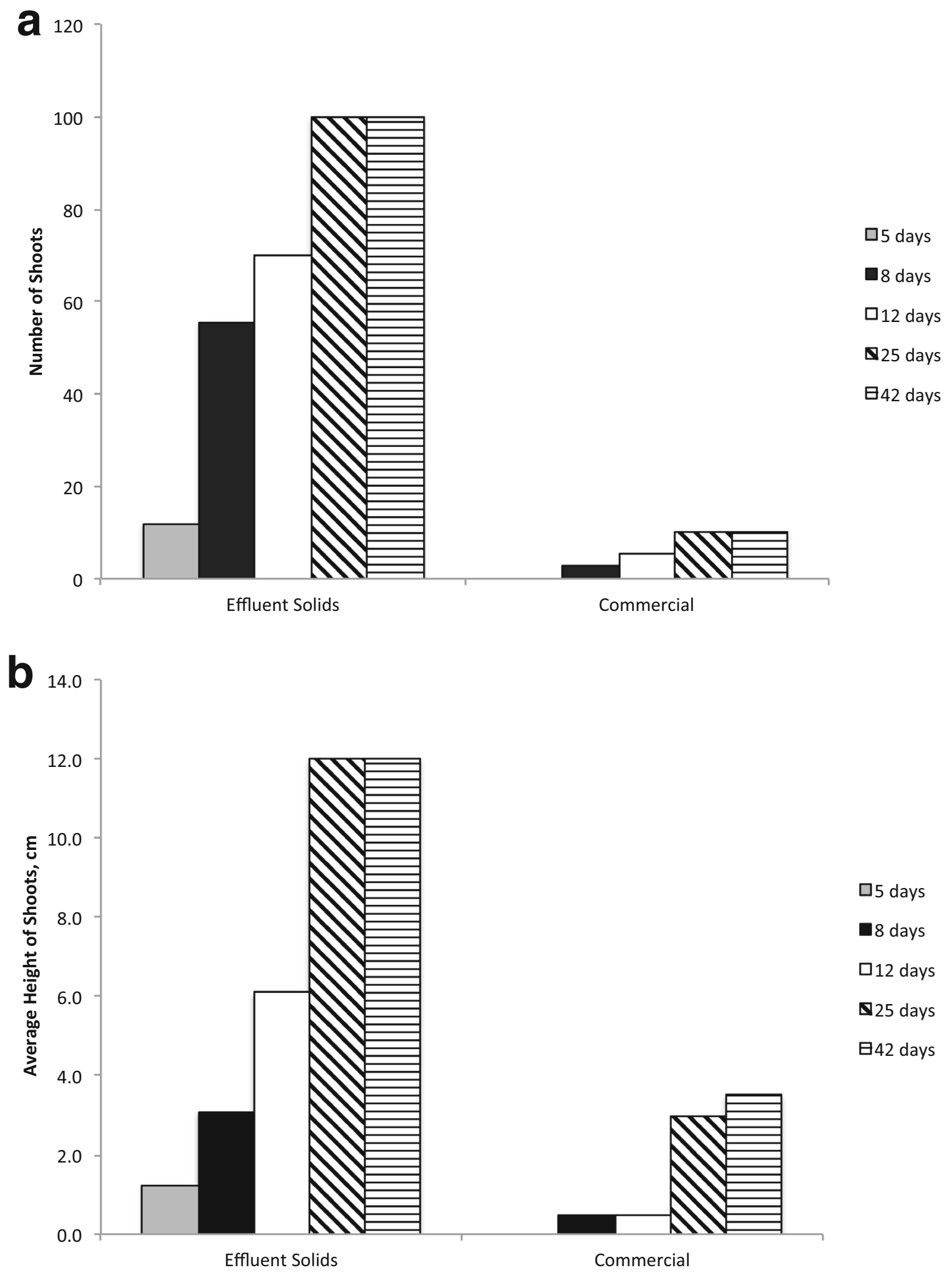

Fig. 4 a The number of grass shoots in soil amended with coal preparation waste anaerobic digestion effluent solids and a commercial fertilizer. b The average height of grass shoots in soil amended with coal preparation waste anaerobic digestion effluent solids and a commercial fertilizer 
Table 2 Kentucky bluegrass ( $P$. pratensis L.) growth tests results (after 42 days)

\begin{tabular}{lll}
\hline Parameter & $\begin{array}{l}\text { Commercial organic } \\
\text { fertilizer }\end{array}$ & $\begin{array}{l}\text { Microbial digestion } \\
\text { effluent solids }\end{array}$ \\
\hline $\begin{array}{l}\text { Number of grass } \\
\text { shoots }\end{array}$ & 10 & 100 \\
$\begin{array}{c}\text { Mean plant } \\
\text { length }(\mathrm{cm})\end{array}$ & 2.5 & 12.8 \\
$\begin{array}{c}\text { Mean root } \\
\text { length }(\mathrm{cm})\end{array}$ & 0.1 & 4.4 \\
$\begin{array}{c}\text { Mean number of } \\
\text { root branches }\end{array}$ & 1 & 13 \\
$\begin{array}{c}\text { Total biomass } \\
\quad(\text { wet })(\mathrm{g})\end{array}$ & 0.02 & 4.07 \\
$\begin{array}{c}\text { Total biomass } \\
(\text { dry) }(\mathrm{g})\end{array}$ & 0.01 & 3.70 \\
\hline
\end{tabular}

waste started decreasing after 90 days and the reactors were stopped after 120 days of operation. The microbial digestion (AD) effluent solids from the coal preparation waste reactors were collected, dried, and analyzed based on the China organic soil amendment standards. Table 1 lists the analytical results for the microbial digestion effluent solids and the raw coal preparation waste. The uptake of heavy metals, such as mercury, by crops entering the food chain is an important concern that should be investigated in any process feedstock and products. As shown in Table 1, the feedstock material and the effluent solids complied with the organic soil amendment standards, where all metals of concern (including mercury) were substantially below the standards. A 35\% decrease in organic matter content was indicated when comparing the results between the raw coal preparation waste and the effluent solids. This indicates that the more readily biodegradable compounds were converted to biogas and potentially microbial biomass, while the remaining organic fraction of the effluent solids was primarily composed of the fragmented, depolymerized, and activated coal compounds.

Microbial digestion process for producing an organic soil amendment, as shown in Fig. 1, is primarily consists of fragmenting/depolymerizing and activating coal compounds in the organic fraction of the coal preparation waste. Since the parent material for the organic fraction of the coal preparation waste was lignite, the likely transformation reactions that occurred during the microbial digestion process were the hydroxylation of catechols and compound side chains, methylation and hydroxylation to form methoxyl groups, alkylation, formation of aryl ether bonds, and increase in compounds similar to cellulose and lignin (Strapoc et al. 2011). Carboxylation, methylation, and hydroxylation of other coal compounds were also likely activation reactions, where some product intermediates were converted to biogas and microbial biomass. A fraction of the compounds may be similar to digestates from $\mathrm{AD}$ of cellulosic waste materials (e.g., agricultural residues), while other compounds may be similar to soil organic matter (SOM), which is largely composed of humic materials. These properties contribute to the potential of using the microbially digested coal preparation waste as organic soil amendments to enhance plant growth, especially in degraded arid soils.

\subsection{Plant growth tests}

The microbial enrichment utilizes activated sludge and cow manure as sources of microorganisms capable of digesting coal compounds. There is likely variation of overall microbiomes from these sources globally; however, the key microorganisms that digest complex organic compounds (such as those in coal) are typically similar around the world. For example, Wu et al. (2019) determined high diversity between activated sludge samples from around the world; however, a global core microbial community linked to activated sludge performance was present in the samples. The reactors used to produce effluent solids from the digestion of coal preparation waste for use in the plant growth tests were inoculated with a microbial enrichment produced from activated sludge and cow manure sourced in Colorado (USA) instead of from Inner Mongolia (China). It was expected that the microbial digestion of the same coal preparation waste would result in a similar product using the Colorado microbial enrichment as with the Inner Mongolia enrichment. As with reactors inoculated with the Inner Mongolia enrichment, the cumulative gas production was significantly higher in Colorado enrichment inoculated reactors containing coal preparation waste than the production from reactors with only the microbial enrichment (Fig. 3a). After 113 days, the total gas production was $17.8 \mathrm{Nm}^{3} / \mathrm{MT}$, which was nearly the same amount produced from the Inner Mongolia enrichment inoculated reactors (which produced $17.6 \mathrm{Nm}^{3}$ total gas/MT). Methane and carbon dioxide composition of the total gas stabilized after 22 days (Figs. 3b, c), where the mean methane composition was $71.0 \%$.

The gas production was an indicator of the microbial digestion of the coal preparation waste, which was stopped after 113 days operation. The effluent solids were collected and used as amendments in a sandy soil where Kentucky bluegrass ( $P$. pratensis L.) was planted. After 42 days of growth, the number of grass shoots and the average height of the shoots (above the soil surface) were 10 and 3 times greater in the soil amended with the effluent solids than in the soil amended with the commercial organic fertilizer (Figs. 4a, b). No growth was observed in soil without any 


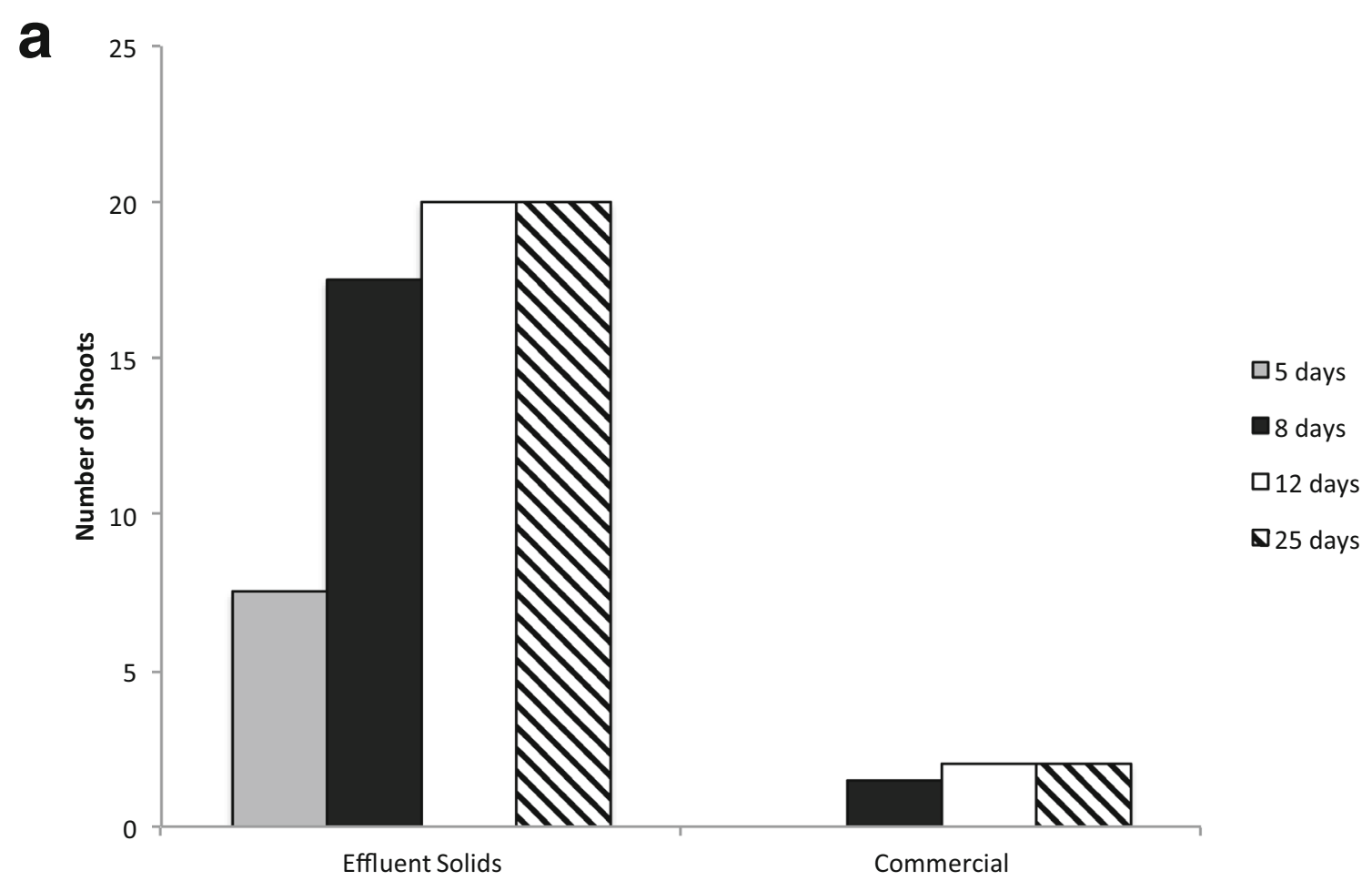

\section{b}

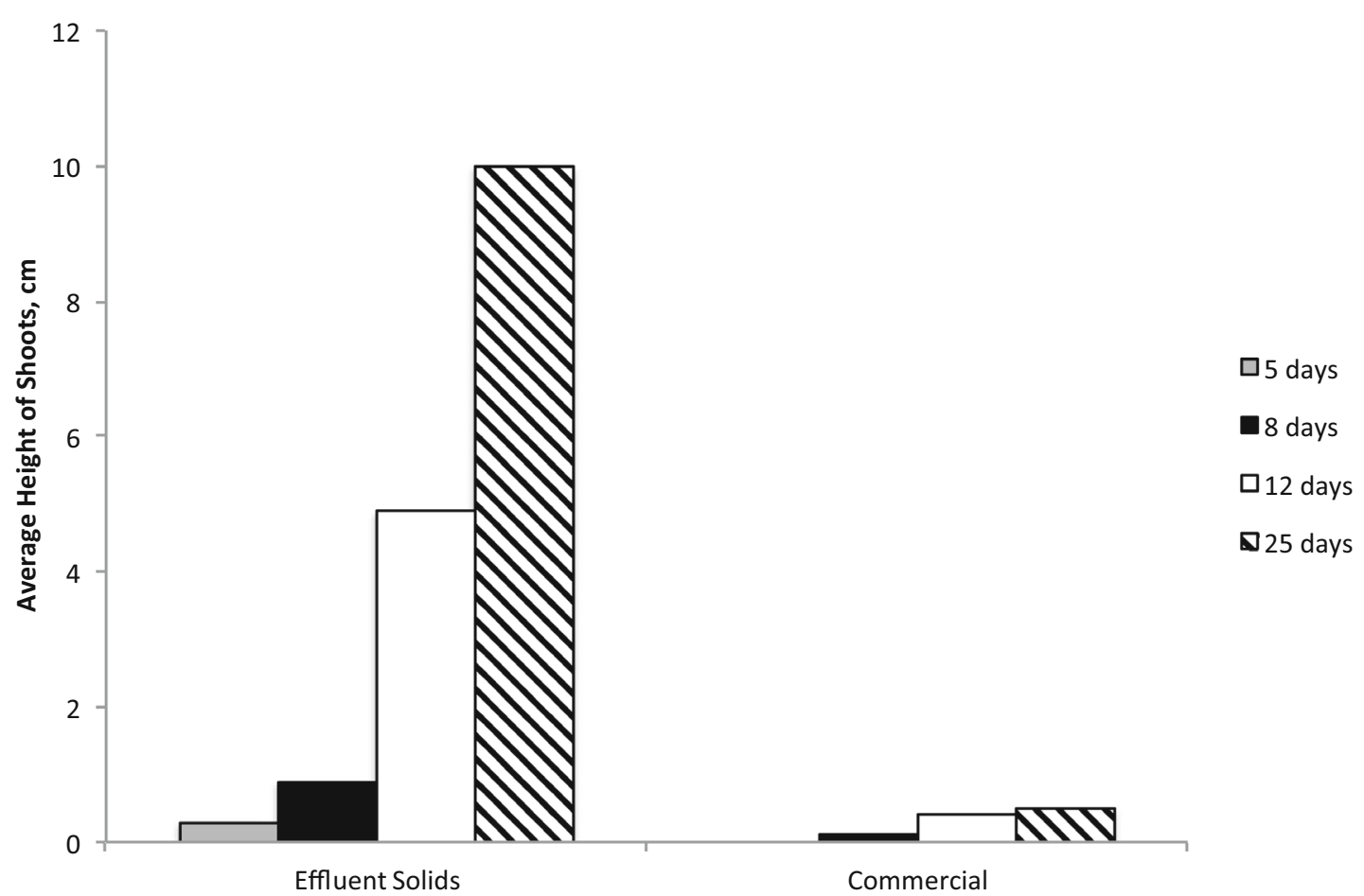

Fig. 5 a The number of chive shoots in soil amended with coal preparation waste anaerobic digestion effluent solids and a commercial fertilizer. b The average height of chive shoots in soil amended with coal preparation waste anaerobic digestion effluent solids and a commercial fertilizer

amendments. Post-harvest analysis results indicated substantially greater grass lengths, root branching, and biomass from the sandy soil amended with the effluent solids than in soil amended with commercial organic fertilizer (Table 2). Total mean grass lengths were 5.1 times greater (note that the grass shoot height indicated earlier was for 
Table 3 Chives (A. schoenoprasum) growth tests results (after 25 days)

\begin{tabular}{lll}
\hline Parameter & $\begin{array}{l}\text { Commercial } \\
\text { organic fertilizer }\end{array}$ & $\begin{array}{l}\text { Microbial digestion } \\
\text { effluent solids }\end{array}$ \\
\hline $\begin{array}{l}\text { Number of chive } \\
\text { shoots }\end{array}$ & 2 & 20 \\
$\begin{array}{l}\text { Mean plant } \\
\text { length (cm) }\end{array}$ & 8.3 & 14.3 \\
$\begin{array}{c}\text { Mean root } \\
\text { length (cm) }\end{array}$ & 1.4 & 4.7 \\
$\begin{array}{c}\text { Mean number of root } \\
\text { branches }\end{array}$ & 4 & 6 \\
$\begin{array}{c}\text { Total biomass } \\
\quad \text { (wet) }(\mathrm{g})\end{array}$ & 0.02 & 0.55 \\
$\begin{array}{c}\text { Total biomass } \\
\text { (dry) (g) }\end{array}$ & 0.01 & 0.35 \\
\hline
\end{tabular}

that observed above the soil surface and did not account for shoot lengths below the soil surface), while the total dry biomass was 370 times greater.

Chives (A. schoenoprasum) were also planted in the sandy soil where the number of chive shoots and, after 25 days, the average height of the shoots were 10 and 20 times greater in the soil amended with the effluent solids than in the soil amended with the commercial organic fertilizer (Figs. 5a, b). After 25 days, the chives were harvested, where post-harvest analysis results indicated substantially greater chive lengths, and biomass from the sandy soil amended with the effluent solids than in soil amended with commercial organic fertilizer (Table 3). Total mean chive lengths were 1.7 times greater, while the total dry biomass was 35 times greater.

Soil organic matter (SOM) is an important and necessary soil component to facilitate plant growth, especially in degraded sandy soils similar to that used for the growth experiments. Microbial activity and growth is another important component of overall soil health and plant growth. Soil microorganisms (primarily bacteria and fungi) contribute to nutrient cycling, nutrient bioavailability, and soil aggregation, where the presence of SOM is necessary to support and maintain these soil microbial activities (Rashid et al. 2016). Both the microbial digestion effluent solids and the commercial organic fertilizer added organic matter to the soil; however, the growth experiment results indicated higher yields of grass and chives for soil amended with the effluent solids when compared to commercial fertilizer. The primary difference between the soil amendments may have been the presence and quantity of microorganisms important to facilitation plant growth.

Long-term effects of amending soil with lignite include higher humic materials (the primary component of SOM) due to slow release of compounds (Kwiatkowska et al. 2008); however, more immediate effects were apparent with the amendment of the microbial digestion effluent solids possibly due to the microorganisms present in the solids. The sandy soil used for the growth experiments had little SOM; therefore, the microbial activity and quantity were likely low. Unlike the commercial organic fertilizer, the microbial digestion effluent solids consisted of still active and dormant microorganisms from the digestion process. This added microbial activity in the soil, thus, likely increased the bioavailability of nutrients and compounds important to plant growth. Overall, through microbial digestion, the coal preparation waste was transformed into a product suitable as a soil amendment to improve SOM content and enhance plant growth, with the potential of reversing soil degradation.

Approximately 75 billion tons of soil (approximately $\$ 400$ billion worth) is lost each year (Eswaran et al. 2001), where, in 2015, the U.S. lost 1.69 billion tons of cropland soil due to erosion (USDA, 2018). Organic fertilizers derived from manures, compost, and other sources (e.g., bone meal) add organic matter to the soil; however, the amount of organic fertilizer that is produced is lower than what would be demanded, due to the limited feedstock, and the favorable effects of organic fertilizer amendments typically do not last multiple growing seasons. The microbial digestion of coal preparation waste into a soil amendment may resolve the issues present with conventional organic soil amendments, where coal preparation waste as feedstock is significantly more abundant. Assuming production of the microbial digestion effluent solids is located in the same location as the coal preparation waste, the cost of the feedstock for producing the effluent solids is negligible; therefore, production costs would be similar to operation costs of other anaerobic digestion processes that treat waste (e.g., wastewater treatment where sludge is recovered and dried for use in agriculture).

Another feature for the coal-based soil amendment is that it does not contain residual antibiotics or other pharmaceutical intermediates. The stringent screening of coal material also eliminates the presence of hazardous metal. In addition, the alternative exit for coal, especially lower grade coal, as a fuel has significant social and economical merits. First of all, the valorization of coal into soil amendment is beneficial to both coal and agricultural industries. Not only will the it raise soil quality and enhance agricultural production, the long term deposit of carbon from coal in the soil also results in the beneficial sequestration of carbon that will be otherwise released in to the environment from combustion. 


\section{Conclusions}

(1) The microbial digestion of the organic fraction from coal preparation waste is feasible based on the production of biogas;

(2) Microbial enrichments that utilize activated sludge and cow manure from different parts of the world perform similarly in digestion coal preparation waste based on biogas production;

(3) The effluent solids from the microbial digestion of coal preparation waste meets the standards for organic soil amendments set by China;

(4) Growth of Kentucky bluegrass and chives can be enhanced in sandy soil amended with the effluent solids; and

(5) The amount of plant growth is substantially greater in soil amended with the effluent solids compared to a commercial organic fertilizer, possibly due to microorganisms present in the effluent solids.

Overall, the microbial digestion of coal preparation waste for application as an organic soil amendment is a viable alternative and beneficial use of one of the most important industrial hazards currently in China.

Acknowledgements The authors thank Ms. Haili Wang and Lili Guo (Apaxfon) and Dr. Zaixing Huang (University of Wyoming) for their assistance in monitoring the bioreactors at each experimental location. The authors also thank Mr. Nick Santiago (Advanced Environmental Technologies) for his assistance in monitoring the growth tests.

Funding The authors declare that the work of Co-author Dr. Liang Chen was partially supported by the National Key R\&D Program of China (2016YFC0401405) and the National Natural Science Foundation of China (No.41772245).

\section{Compliance with Ethical Standards}

Conflict of interest The authors declare that they have no known competing financial interests or personal relationships that could have appeared to influence the work reported in this paper.

Open Access This article is licensed under a Creative Commons Attribution 4.0 International License, which permits use, sharing, adaptation, distribution and reproduction in any medium or format, as long as you give appropriate credit to the original author(s) and the source, provide a link to the Creative Commons licence, and indicate if changes were made. The images or other third party material in this article are included in the article's Creative Commons licence, unless indicated otherwise in a credit line to the material. If material is not included in the article's Creative Commons licence and your intended use is not permitted by statutory regulation or exceeds the permitted use, you will need to obtain permission directly from the copyright holder. To view a copy of this licence, visit http://creativecommons. org/licenses/by/4.0/.

\section{References}

Akiyama T, Kawamura K (2007) Grassland degradation in China: methods of monitoring, management and restoration. Grassland Sci 53:1-17

Cubillos-Hinojosa JG, Valero NO, Melgarejo LM (2015) Assessment of a low rank coal inoculated with coal solubilizing bacteria as an organic amendment for a saline-sodic soil. Chem Biol Technol Agric 2:21

David Y, Baylon MG, Pamidimarri SDVN, Baritugo K-A, Chae CG, Kim YJ, Kim TW, Kim M-S, Na JG, Park SJ (2017) Screening microorganisms able to degrade low-rank coal in aerobic conditions: potential coal biosolubilization midiators from coal to biochemical. Biotechnol Bioproc Eng 22:178-185

Eswaran H, Lal R, Reich PF (2001) Land degradation: an overview. In: Bridges EM, Hannam ID, Oldeman LR, Pening de Vries FWT, Scherr SJ, Sompatpanit S (Eds.) Responses to land degradation, Proc 2nd International Conference on Land Degradation and Desertification, Khon Kaen, Thailand, Oxford Press, New Delhi, India. Retrieved from: https://www.nrcs.usda.gov/ $\mathrm{wps} / \mathrm{portal} / \mathrm{nrcs} / \mathrm{detail} / \mathrm{soils} / \mathrm{use} /$ ?cid=nrcs142p2_054028. (01/28/ 2019)

Faison BD (1991) Microbial conversions of low rank coals. Nat Biotechnol 9:951-956

Fallgren PH, Jin S, Zeng C, Ren Z, Lu A, Colberg PJS (2013) Comparison of coal rank for enhanced biogenic natural gas production. Int J Coal Geol 115:92-96

Fallgren PH, Zeng C, Ren Z, Lu A, Ren S, Jin S (2013) Feasibility of microbial production of new gas from non-gas producing lignite. Int J Coal Geol 115:79-84

Fiscor S (2016) Pure-gro develops coal-based fertilizer. Coal Age 121(8):30-32

Fu T, Wu Y, Ou L, Yang G, Liang T (2012) Effects of thin covers on the release of coal gangue contaminants. Energy Procedia 16:327-333

Gao Y, Huang H, Tang W, Liu W, Yang X, Zhang J (2015) Preparation and characterization of a novel porous silicate material from coal gangue. Micropor Mesopor Mat 217:210-218

Giannouli A, Kalaitzidis S, Siavalas G, Chatziapostolou A, Christanis K, Papazisimou S, Papanicolaou C, Foscolos A (2009) Evaluation of Greek low-rank coals as potential raw material for the production of soil amendments and organic fertilizers. Int. J Coal Geol 77:383-393

Gokcay CF, Kolankaya N, Dilek FB (2001) Microbial solubilization of lignites. Fuel 80:1421-1433

Gupta P, Gupta A (2014) Biogas production from coal via anaerobic fermentation. Fuel 118:238-242

Gupta A, Birendra K (2000) Biogasification of coal using different sources of microorganisms. Fuel 79:103-105

Huang Z, Liu F, Urynowicz MA, Basile F, Guo H, Chen L, Fallgren $\mathrm{PH}$, Jin S (2018) Coal-derived compounds and their potential impact on groundwater quality during coalbed methane production. Environ Geochem Health 40:1657-1665

Huang Z, Liers C, Ulrich R, Hofrichter M, Urynowicz MA (2013) Depolymerization and solubilization of chemically pretreated Powder river basin subbituminous coal by manganese peroxidase (MnP) from bierkandera adusta. Fuel 112:295-301

Isbister JD, Barik S (1993) Biogasification of low rank coals. In: Crawford DL (ed) Microbial transformations of low rank coals. CRC Press, Boca Raton, FL, pp 139-156

Jin S (2007) Enhancement of biogenic methane production and back injection of coalbed methane co-produced water. Final report to U.S. Department of Energy, WRI 07-R008. 
Kirn A, Kashif SR, Yaseen M (2010) Using indigenous humic acid from lignite to increase growth yield of okra (Abelmoschus esculentus L). Soil Environ 29(2):187-191

Kwiatkowska J, Provenzano MR, Senesi N (2008) Long term effects of a brown coal-based amendment on the properties of soil humic acids. Geoderma 148:200-205

Li L, Lei Y, Pan D (2015) Economic and environmental evaluation of coal production in China and policy implications. Nat Hazards $77: 1125-1141$

Li H, Sun H, Xiao X, Chen H (2006) Mechanical properties of gangue-containing aluminosilicate based cementitious materials. J Univ Sci Technol Beijing 13:183-189

Liang Y, Liang H, Zhu S (2016) Mercury emission from spontaneously ignited coal gangue hill in Wuda coalfield, Inner Mongolia, China. Fuel 182:525-530

Liu F, Guo H, Wang Q, Haider R, Urynowicz MA, Fallgren PH, Jin S, Tang M, Chen B, Huang Z (2019) Characterization of organic compounds from hydrogen peroxide-treated subbituminous coal and their composition changes during microbial methanogenesis. Fuel 237:1209-1216

Nkoa R (2014) Agricultural benefits and environmental risks of soil fertilization with anaerobic digestates: a review. Agron Sustain Dev 34:473-492

Rashid MI, Mujawar LH, Shahzad T, Almeelbi T, Ismail IMJ, Oves M (2016) Bacteria and fungi can contribute to nutrients bioavailability and aggregate formation in degraded soils. Microbiol Res 183:26-41

Strapoc D, Mastalerz M, Dawson K, Macalady J, Callaghan AV, Wawrik B, Turich C, Ashby M (2011) Biogeochemistry of microbial coal-bed methane. Annu Rev Earth Planet Sci 39:617-656

Strapoc D, Picardal FW, Turich C, Schaperdoth I, Macalady JL, Lipp JS, Lin Y-S, Ertefai TF, Schubotz F, Hinrichs K-U, Mastalerz M, Schimmelmann A (2008) Methane-producing microbial community in a coal bed of the Illinois Basin. Appl Environ Microbiol 74:2425-2432

Stoner DL, Wey JE, Barrett KB, Jolley JG, Wright RB, Dugan PR (1990) Modification of water-soluble coal-derived products by dibenzothiophene-degrading microorganisms. Appl Environ Microbiol 56:2667-2676
Sudheer PDVN, David Y, Chae CG, Kim YJ, Baylon MG, Baritugo K-A, Kim M-S, Na JG, Park SJ (2016) Advances in the biological treatment of coal for synthetic natural gas and chemicals. Korean J Chem Eng 33:2788-2801

USDA (US Department of Agriculture) (2018) Summary report: 2015 National resources inventory. Natural conservation service, Washington, DC, and center for survey statistics and methodology, Iowa State University, Ames, Iowa. Retrieved from: https://www.nrcs.usda.gov/internet/FSE_DOCUMENTS/ nrcseprd1422028.pdf (01/28/2019)

Wang Q, Guo H, Wang H, Urynowicz MA, Hu A, Yu C, Fallgren P, Jin S, Zheng H, Zeng RJ, Liu F, Chen B, Zhang RA, Huang Z (2019) Enhanced production of secondary biogenic coalbed natural gas from a subbituminous coal treated by hydrogen peroxide and its geochemical and microbiological analyses. Fuel 236:1345-1355

Wang L, Zhang W, Guo G, Qian K, Huang X (2009) Selection experiments for the optimum combination of AMF-plantsubstrate for the restoration of coal mines. Mining Sci Technol 19:479-482

Wu L, Ning D, Zhang B, Li Y, Zhang P, Shan X, Zhang Q, Brown MR, Li Z, van Nostrand JD, Ling F, Xiao N, Zhang Y, Vierheilig J, Wells GF, Yang Y, Deng Y, Tu Q, Wang A, Zhang T, He Z, Keller J, Nielsen PH, Alvarez PJJ, Criddle CS, Wagner M, Tiedje JM, He Q, Curtis TP, Stahl DA, Alvarez-Cohen L, Rittmann BE, Wen X, Zhou J (2019) Global diversity and biogeography of bacterial communities in wastewater treatment plants. Nat Microbiol 4:1183-1195

Yan DH, Karstensen KH, Huang QF, Wang Q, Cai ML (2010) Coprocessing of industrial and hazardous wastes in cement kilns: a review of current status and future needs in China. Environ Eng Sci 27:37-45

Zhao C, Luo K (2017) Sulfur, arsenic, fluorine and mercury emissions resulting from coal-washing byproducts: a critical component of China's emission inventory. Atmos Environ 152:270-278

Zhou C, Liu G, Wu D, Fang T, Wang R, Fan X (2014) Mobility behavior and environmental implications of trace elements associated with coal gangue: a case study at the huainan coalfield in China. Chemosphere 95:193-199 